\title{
Carbohydrate Metabolism of Iron-Rich and Iron-Poor Staphylococcus aureus
}

\author{
By T. S. THEODORE AND A. L. SCHADE \\ Department of Health, Education and Welfare, Public Health Service, National \\ Institutes of Health, National Institute of Allergy and Infectious \\ Diseases, Bethesda, Maryland, U.S.A.
}

(Received 25 March 1965)

\begin{abstract}
SUMMARY
Comparative studies were made of the metabolic activities of a strain of Staphylococcus aureus grown in iron-poor and iron-rich trypticase medium, with and without glucose. Four nutritionally distinctive types of organisms were produced: iron-rich without glucose $(\mathbf{F e}+\mathbf{G}-)$; ironpoor without glucose $(\mathrm{Fe}-\mathbf{G}-)$; iron-rich with glucose $(\mathbf{F e}+\mathbf{G}+)$; iron-poor with glucose $(\mathbf{F e}-\mathbf{G}+)$. $\mathbf{F e}+\mathbf{G}-$ cocci oxidized glucose, $\mathrm{L}$ - and $\mathrm{D}$-lactate, pyruvate, acetate, formate, and Krebs cycle intermediates to completion. Of these substrates, only glucose and the lactates were oxidized by the $\mathrm{Fe}-\mathrm{G}-$ organisms. These latter oxidations proceeded at decreased rates and incompletely to acetate and acetoin. $\mathrm{Fe}+\mathbf{G}+$ cocci in comparison with the $\mathbf{F e}+\mathbf{G}-$ cocci showed glucose inhibition of oxidative capacity by metabolizing only glucose, L-lactate and pyruvate to acetate and failing to oxidize D-lactate, acetate and Krebs cycle intermediates. The $\mathrm{Fe}-\mathrm{G}+$ cocci showed the most severe restriction of oxidative capacity by oxidizing only glucose with the accumulation of much lactate and minor amounts of pyruvate, acetate and acetoin. The $\mathrm{Fe}-\mathrm{G}-, \mathrm{Fe}-\mathrm{G}+$, and $\mathrm{Fe}+\mathrm{G}+$ cocci glycolysed glucose at comparable rates, while the highly oxidative form $\mathbf{F e}+\mathbf{G}-$ showed a markedly decreased glycolytic activity. The catalase activity of both types of iron-poor cocci was very much lower than that of the iron-rich organisms. Of the latter, the $\mathrm{Fe}+\mathrm{G}+$ cocci showed a catalase activity only $20 \%$ that of $\mathbf{F e}+\mathbf{G}-$ cocci.
\end{abstract}

\section{INTRODUCTION}

The growth characteristics of Staphylococcus aureus in complex media of various iron availabilities have recently been reported (Theodore \& Schade, 1965). Not only the rate of growth but also the final size of the population were dependent upon the concentration of free iron in the medium. Preliminary investigations of the metabolic effects of nutritional iron deficiency showed that iron restriction of growing $S$. aureus resulted in qualitatively and quantitatively altered aerobic metabolism of common carbon sources (Schade, 1963). Since iron is required for the formation of haemoproteins essential for many enzymically catalysed biological oxidation-reduction reactions and thus must be provided in the growth media of practically all micro-organisms, the possible metabolic alterations produced in $S$. aureus by iron-deficiency have been examined. Such a study is of significance since 
the nutritional conditions provided by the circulating animal body fluids approximate an iron-restricted state for $S$. aureus affected by the iron-chelating activity of their contained siderophilin [transferrin], (Schade, 1960). A more satisfactory understanding of the pathogenicity of $S$. aureus can be anticipated from the knowledge of its metabolic characteristics as they are determined by iron restriction, rather than from that derived from previous studies of organisms grown in media containing essentially excess iron. In the present work, comparative studies of the oxidative and glycolytic activities of suspensions of iron-rich and iron-poor $S$. aureus were made. In an attempt to determine the site of action of iron in the metabolism of these organisms, qualitative and quantitative analyses of the end products formed from various carbohydrate intermediates have been made.

\section{METHODS}

Organism. A penicillin resistant strain of Staphylococcus aureus, phage type $80 / 81$, was used throughout. Stock cultures on nutrient agar slopes were kept in the cold and subcultured every 2 months.

Media. The basal medium used for the production of iron-rich and iron-deficient organisms contained: $2 \%(\mathrm{w} / \mathrm{v})$ iron-depleted trypticase medium (0.01-0.02 $\mu \mathrm{g}$. $\mathrm{Fe} / \mathrm{ml}.) ; 1 \%(\mathrm{v} / \mathrm{v})$ egg white $(1.0 \mathrm{ml}$. egg white through its contained conalbumin binds about $20 \mu \mathrm{g}$. iron, Schade \& Caroline, 1944); growth factor amounts of biotin $(0.11 \mu \mathrm{g} . / \mathrm{ml}$.$) , nicotinic acid (0.05 \mu \mathrm{g} . / \mathrm{ml}$.), thiamine $\mathrm{HCl}(0.05 \mu \mathrm{g} . / \mathrm{ml}$.$) . When$ desired, glucose was added to the medium to a final concentration $0 \cdot 2 \%(w / v)$. All

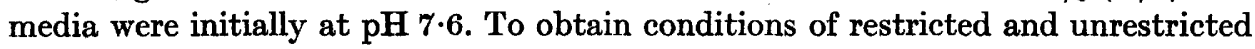
iron availability, iron as ferrous ammonium sulphate $\left(\mathrm{Fe}\left(\mathrm{NH}_{4}\right)_{2}\left(\mathrm{SO}_{4}\right)_{2} \cdot 6 \mathrm{H}_{2} \mathrm{O}\right.$; Fisher C. P.) was added to the media at 0.01 and $0.228 \mu \mathrm{g} . / \mathrm{ml}$. The resulting percentages iron saturation of the egg-white conalbumin were 10-15 and 115-120 respectively. Procedures for cleaning glassware, removal of iron from the trypticase medium (Baltimore Biological Laboratories, 0.6-0.8 $\mu \mathrm{g} . \mathrm{Fe} / \mathrm{ml}$.), and the preparation of various medium components were described in a previous paper (Theodore \& Schade, 1965). Media were dispensed in $500 \mathrm{ml}$. batches in 21 . screw-capped Erlenmeyer flasks. Seed cultures were grown at $37^{\circ}$ for $12 \mathrm{hr}$ in iron-depleted trypticase $(2 \%)$ medium without egg white or glucose.

Preparation of washed coccal suspensions. For manometric studies and for determining products of glycolysis and oxidation of substrates, suspensions of Staphylococcus aureus were prepared from log-phase cocci grown in iron-deficient and ironenriched media, in absence or presence of glucose. Organisms grown in these media will be referred to herein as: $\mathbf{F e}-\mathbf{G}-$ cocci, $\mathrm{Fe}+\mathrm{G}-$ cocci, $\mathrm{Fe}-\mathrm{G}+$ cocci and $\mathrm{Fe}+\mathrm{G}+$ cocci, respectively. Five hundred $\mathrm{ml}$. of the appropriate media were inoculated with $0.3 \mathrm{ml}$. of a 1/100 dilution of the seed culture which had an extinction $E_{600 \mathrm{~m} \mu}^{1.0 \mathrm{~cm}}$ of approximately 0.3 , and incubated at $37^{\circ}$ on a rotary shaker. The incubation times and the final $\mathrm{pH}$ values of the cultures grown in the four media and harvested while still in their logarithmic phase of growth were: $(\mathrm{Fe}-\mathrm{G}-) 13 \mathrm{hr}$, pH 7.5; $(\mathrm{Fe}+\mathrm{G}-) 10 \mathrm{hr}, \mathrm{pH} \mathrm{7.7} ;(\mathrm{Fe}-\mathrm{G}+) 12 \mathrm{hr}, \mathrm{pH} \mathrm{7.5} ;(\mathrm{Fe}+\mathrm{G}+) 9 \mathrm{hr}$, pH 6.5; respectively. At harvest the cultures were passed through Pyrex glass wool filtering fibre and centrifuged at $4^{\circ}$ at $4000 \mathrm{~g}$ for $20 \mathrm{~min}$. Analyses for glucose in the supernatant fluids of all cultures were positive only in those from the high- and 
low-Fe + glucose media. For oxygen uptake studies, cocci were washed twice with $0 \cdot 1 \mathrm{M}$-phosphate buffer $(\mathrm{pH} 7 \cdot 4)$ and resuspended in the same buffer. Organisms used for the measurement of glycolytic activity were washed twice and resuspended in $0.03 \mathrm{M}-\mathrm{NaHCO}_{3}$ buffer ( $\mathrm{pH} \mathrm{7.4)}$. For the manometric assay of catalase activity, the cocci were washed and resuspended in $0.85 \%(\mathrm{w} / \mathrm{v}) \mathrm{NaCl}$. All suspensions were diluted to an extinction at $600 \mathrm{~m} \mu$ appropriate to their intended use. Preliminary analytical studies established that a $E_{600 \mathrm{~m} \mu}^{1.0 \mathrm{~cm}}$ of 1.0 was equivalent to approximately $320 \mu$ g. dry wt. organism $/ \mathrm{ml}$. and $2 \times 10^{9}$ cocci $/ \mathrm{ml}$. of the suspension measured. These values were applicable to the organisms grown in all four media.

Analytical procedures. Standard Warburg manometric techniques were used for measuring $\mathrm{O}_{2}$ uptake and $\mathrm{CO}_{2}$ production (Umbreit, Burris, \& Stauffer, 1957). The main chamber contained $2.0 \mathrm{ml}$. washed coccal suspension (equiv. 3.2 $\mathrm{mg}$. dry wt.) and the substrates in the sidearms were added in 0.1 and $0.2 \mathrm{ml}$. amounts. The temperature was maintained at $37^{\circ}$. For analysis of the products of glycolysis and oxidation of the substrates used, duplicate Warburg vessels were shaken in the bath with the same proportion of cocci to substrate and were set up in conjunction with the manometric experiment. Following complete utilization of the substrate, as measured manometrically, the vessels were chilled and samples removed, centrifuged in the cold, and the supernatant fluids frozen and kept for analysis.

Catalase activity was assayed for manometrically (Schade, 1963). Iron analysis of the medium and the iron-binding capacity of the egg white were determined by the bound-iron and unsaturated iron-binding capacity methods of Schade, Oyama, Reinhart \& Miller (1954). Glucose was determined by glucostat (Worthington Biochemical Corp., Freehold, New Jersey). Pyruvate remaining in the supernatant fluids was assayed as the 2,4-dinitrophenylhydrazone, with benzene extraction (Friedemann \& Haugen, 1943); lactate was determined by the method of Barker \& Summerson (1941); acetoin was measured by the method of Westerfeld (1945); acetate was determined enzymically by the method of Soodak (1957).

\section{RESULTS}

\section{Oxidative activities of iron-rich and iron-poor Staphylococcus aureus}

The oxidative capabilities of iron-rich and iron-poor staphylococci, when grown in the presence or absence of glucose, were measured with common glycolytic and Krebs cycle intermediates at non-limiting substrate concentrations (Table 1). $\mathbf{F e}+\mathbf{G}$ - suspensions oxidized glucose, L-lactate, malate, D-lactate pyruvate, acetate and formate. In contrast, $\mathrm{Fe}-\mathrm{G}-$ suspensions oxidized glucose, L-lactate and $\mathrm{D}$ lactate at approximately one-half to one-third the rate of that of the $\mathrm{Fe}+\mathrm{G}-$ cocci. Malate oxidation was greatly suppressed while pyruvate, acetate and formate were not utilized. Thus, it is clear that the growth of Staphylocossus aureus in an ironrestricted medium resulted in organisms with impaired respiratory activity. When $\mathrm{Fe}+\mathbf{G}+$ suspensions were similarly examined (Table 1), they oxidized glucose, L-lactate, $\mathrm{D}$-lactate, pyruvate and formate at more or less severely decreased rates as compared with those found with $\mathrm{Fe}+\mathrm{G}$ - cocci; for example, the $\boldsymbol{Q}_{\mathrm{o}_{2}}$ on pyruvate showed an eightfold difference. $\mathbf{F e}-\mathbf{G}+$ suspensions were completely devoid of any activity on these same substates except for a very small rate of oxidation of glucose. 


\title{
End product analysis studies on iron-rich and iron-poor suspensions grown in the absence of glucose
}

Since differences in oxidative rates were found as between suspensions of ironrich and iron-poor staphylococci on various selected substrates, the effects of iron deficiency on the qualitative and quantitative results of such oxidations were studied. With limiting amounts of various substrates, total $\mathrm{O}_{2}$ uptake and $\mathrm{CO}_{2}$ production were determined and analyses for the accumulated end products were made. Figure 1 summarizes the manometric measurements of $\mathrm{O}_{2}$ consumption by $\mathrm{Fe}+\mathrm{G}-$ and $\mathrm{Fe}-\mathrm{G}-$ suspensions. Formate, acetate, succinate, malate, and to a

Table 1. Rate of oxidation of various substrates by suspensions of iron-rich and ironpoor Staphylococcus aureus grown in the absence or presence of glucose

\begin{abstract}
Warburg vessels contained equiv. $3.2 \mathrm{mg}$. dry wt. cocci in $2.0 \mathrm{ml}$. $0.1 \mathrm{~m}$-potassium phosphate buffer (pH 7.4); $25 \mu$ mole substrate were added from the side-arm; total volume $2.4 \mathrm{ml}$. The centre well contained $0.2 \mathrm{ml}$. $10 \%(\mathrm{w} / \mathrm{v}) \mathrm{KOH}$; the gas phase was air. The $Q_{O_{2}}$ values represent $\mu \mathrm{l} . \mathrm{O}_{2}$ consumed/hr./mg. dry wt. cocci, calculated on the maximum rate of oxygen consumption following a $10 \mathrm{~min}$. initial equilibration period and corrected for the endogenous rate.
\end{abstract}

\begin{tabular}{|c|c|c|c|c|}
\hline \multirow[t]{2}{*}{ 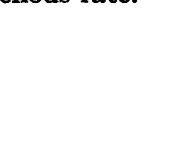 } & \multicolumn{4}{|c|}{ Coceal suspension } \\
\hline & $\mathbf{F e}-\mathbf{G}-$ & $\mathrm{Fe}+\underset{Q_{\mathrm{O}_{\mathbf{2}}} \mathbf{v}}{\mathrm{G}-}$ & $\begin{array}{l}\mathrm{Fe}-\mathbf{G}+ \\
\text { alues }\end{array}$ & $\mathbf{F e}+\mathbf{G}+*$ \\
\hline \multicolumn{5}{|l|}{ Substrate } \\
\hline Endogenous & 6 & 23 & $\mathbf{2}$ & 13 \\
\hline Glucose & 101 & $\mathbf{3 1 6}$ & 23 & 104 \\
\hline L-Lactate & 143 & 306 & $\mathbf{0}$ & 87 \\
\hline D-Lactate & $\mathbf{3 3}$ & 105 & $\mathbf{0}$ & 22 \\
\hline Pyruvate & $\mathbf{0}$ & 202 & $\mathbf{0}$ & 26 \\
\hline Acetate & 0 & 124 & $\mathbf{0}$ & 0 \\
\hline Formate & $\mathbf{0}$ & 124 & $\mathbf{0}$ & 63 \\
\hline Malate & 7 & 58 & $\mathbf{0}$ & 0 \\
\hline
\end{tabular}

* Fe $-\mathrm{G}-, \mathrm{Fe}+\mathrm{G}-, \mathrm{Fe}-\mathrm{G}+, \mathrm{Fe}+\mathrm{G}+$ mean respectively, Fe poor without glucose; Fe rich, without glucose; Fe poor, with glucose; Fe rich, with glucose.

lesser extent citrate, were oxidized by $\mathbf{F e}+\mathbf{G}-$ cocci. End-product analysis showed that formate and acetate were oxidized completely with 92 and $96 \%$ of the carbon accounted for as $\mathrm{CO}_{2}$, respectively (Table 2). Fe - G - coccal suspensions, as shown in Fig. 1 and Table 2, were unable to use any of these substrates. It appeared possible that the $\mathrm{Fe}-\mathrm{G}$ - cocci contained all the enzymes necessary for the oxidation of the above substrates, but that one or more were present as apoenzymes which required free ionic iron for the completion of activation. To test this, suspensions of $\mathbf{F e}-\mathrm{G}$ - cocci were pre-incubated in Warburg vessels with $\mathbf{3 \cdot 0} \mu \mathrm{g}$. iron for $30 \mathrm{~min}$. at $37^{\circ}$; then formate and acetate were tipped into the suspensions. No $\mathrm{O}_{2}$ uptake was observed.

Suspensions of $\mathrm{Fe}+\mathrm{G}-$ and $\mathrm{Fe}-\mathrm{G}-$ cocci were examined for their ability to oxidize glucose and various intermediates of glycolysis (Fig. 2). Fe+ G- cocci oxidized glucose, L-lactate, D-lactate and pyruvate essentially to completion (Table 2). In all cases the only major end-product was $\mathrm{CO}_{2}$. The difference in the amount of carbon initially provided and that accounted for as $\mathrm{CO}_{2}$ produced 
Metabolism of Fe-poor staphylococci
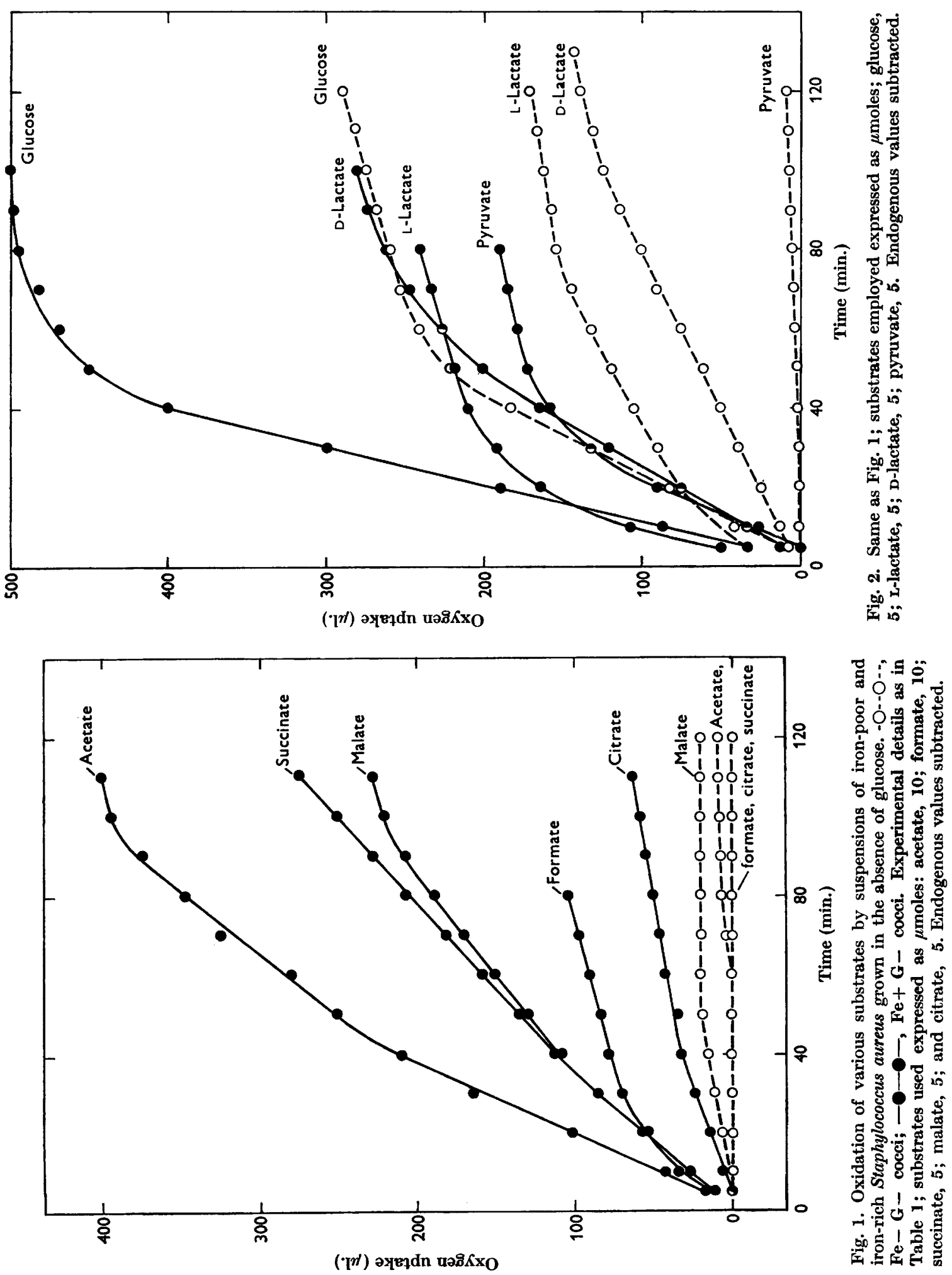
probably indicated assimilated carbon. Fe - G - cocci, on the other hand, oxidized glucose, L-lactate and D-lactate at a decreased rate and effected a much smaller total $\mathrm{O}_{2}$ consumption by the time the utilization of added substrate had practically ceased (Fig. 2). Pyruvate, in contrast to the results obtained with $\mathrm{Fe}+\mathbf{G}-$ cocci, was not oxidized. As calculated from the data in Table 2, the products of glucose oxidation by $\mathbf{F e}-\mathbf{G}$ - cocci as percentages of the initial carbon available were: $\mathrm{CO}_{2}, 46 \%$; acetate, $28 \%$; acetoin, $9 \%$. L-Lactate was oxidized to $\mathrm{CO}_{2}, 49 \%$, acetate, $18 \%$; and acetoin, $10 \%$. From D-lactate no acetoin was found, only $\mathrm{CO}_{2}$, $45 \%$ and acetate, $27 \%$. When acetoin was offered to high-Fe and to low-Fe cocci, none was utilized. Attempts to recover some part of the 17, 23, and $29 \%$ of the unaccounted-for carbon from the glucose, L-lactate and $\mathrm{D}$-lactate oxidations respectively, as acetaldehyde or pentose sugars, were unsuccessful. It is assumed that

Table 2. Substrate dissimilation by suspensions of iron-rich and iron-poor Staphylococcus aureus grown in the absence of glucose*

Experimental details as for Figs. 1 and 2

\begin{tabular}{|c|c|c|c|c|c|c|c|c|c|}
\hline Substrate & Organisms & Lactate & Pyruvate & Acetate & Acetoin & $\mathrm{CO}_{2}$ & $\mathrm{O}_{2}$ & R.Q. & $\begin{array}{c}\% \\
\text { carbon } \\
\text { recovered }\end{array}$ \\
\hline Glucose $†$ & $\begin{array}{l}\mathrm{Fe}+\mathbf{G}- \\
\mathrm{Fe}-\mathbf{G}-\end{array}$ & $\begin{array}{l}\mathbf{0} \\
\mathbf{0}\end{array}$ & $\begin{array}{l}0 \\
0\end{array}$ & $\begin{array}{l}0 \\
0.851\end{array}$ & $\begin{array}{l}0 \\
0 \cdot 141\end{array}$ & $\begin{array}{l}4.31 \\
2.74\end{array}$ & $\begin{array}{l}4 \cdot 42 \\
2 \cdot 52\end{array}$ & $\begin{array}{l}0.98 \\
1.09\end{array}$ & $\begin{array}{l}72 \\
83\end{array}$ \\
\hline L-Iactate & $\begin{array}{l}\mathrm{Fe}+\mathrm{G}- \\
\mathrm{Fe}-\mathrm{G}-\end{array}$ & $\begin{array}{l}\mathbf{0} \\
\mathbf{0}\end{array}$ & $\begin{array}{l}\mathbf{0} \\
\mathbf{0}\end{array}$ & $\begin{array}{l}0 \\
0 \cdot 273\end{array}$ & $\begin{array}{l}0 \\
0.077\end{array}$ & $\begin{array}{l}2 \cdot 04 \\
1.46\end{array}$ & $\begin{array}{l}2 \cdot 02 \\
1 \cdot 46\end{array}$ & $\begin{array}{l}1 \cdot 01 \\
1 \cdot 00\end{array}$ & $\begin{array}{l}68 \\
77\end{array}$ \\
\hline D-Lactate & $\begin{array}{l}\mathbf{F e}+\mathbf{G}- \\
\mathbf{F e}-\mathbf{G}-\end{array}$ & $\begin{array}{l}\mathbf{0} \\
\mathbf{0}\end{array}$ & $\begin{array}{l}\mathbf{0} \\
\mathbf{0}\end{array}$ & $\begin{array}{l}0 \\
0 \cdot 399\end{array}$ & $\begin{array}{l}0 \\
0\end{array}$ & $\begin{array}{l}2 \cdot 52 \\
1 \cdot 34\end{array}$ & $\begin{array}{l}2 \cdot 50 \\
1 \cdot 26\end{array}$ & $\begin{array}{l}1.01 \\
1.06\end{array}$ & $\begin{array}{l}84 \\
71\end{array}$ \\
\hline Pyruvate & $\begin{array}{l}\mathrm{Fe}+\mathrm{G}- \\
\mathrm{Fe}-\mathrm{G}-\end{array}$ & $\begin{array}{l}0 \cdot 05 \\
0\end{array}$ & $\begin{array}{l}0 \\
0.97\end{array}$ & $\begin{array}{l}\mathbf{0} \\
\mathbf{0}\end{array}$ & $\begin{array}{l}\mathbf{0} \\
\mathbf{0}\end{array}$ & $\begin{array}{l}2 \cdot 18 \\
0\end{array}$ & $\begin{array}{l}1 \cdot 64 \\
0\end{array}$ & $\begin{array}{c}1.33 \\
-\end{array}$ & $\begin{array}{l}78 \\
97\end{array}$ \\
\hline Acetate & $\begin{array}{l}\mathrm{Fe}+\mathbf{G}- \\
\mathrm{Fe}-\mathbf{G}-\end{array}$ & $\begin{array}{l}\mathbf{0} \\
\mathbf{0}\end{array}$ & $\begin{array}{l}\mathbf{0} \\
\mathbf{0}\end{array}$ & $\begin{array}{l}0.052 \\
1 \cdot 01\end{array}$ & $\begin{array}{l}\mathbf{0} \\
\mathbf{0}\end{array}$ & $\begin{array}{l}1 \cdot 81 \\
0\end{array}$ & $\begin{array}{l}1 \cdot 75 \\
0\end{array}$ & $\begin{array}{c}1 \cdot 03 \\
-\end{array}$ & $\begin{array}{r}96 \\
101\end{array}$ \\
\hline Formate & $\begin{array}{l}\mathrm{Fe}+\mathrm{G}- \\
\mathrm{Fe}-\mathrm{G}-\end{array}$ & $\begin{array}{l}\mathbf{0} \\
\mathbf{0}\end{array}$ & $\begin{array}{l}\mathbf{0} \\
\mathbf{0}\end{array}$ & $\begin{array}{l}0 \\
0\end{array}$ & $\begin{array}{l}\mathbf{0} \\
\mathbf{0}\end{array}$ & $\begin{array}{l}0 \cdot 92 \\
0\end{array}$ & $\begin{array}{l}0 \cdot 56 \\
0\end{array}$ & $\begin{array}{l}1 \cdot 70 \\
-\end{array}$ & 92 \\
\hline
\end{tabular}

* Results expressed as $\mu$ mole $/ \mu$ mole substrate consumed. $\mathrm{O}_{2}$ and $\mathrm{CO}_{2}$ corrected for endogenous.

$\uparrow$ No glucose detected in supernatant fluids.

the unrecovered carbon had been assimilated. The observed respiratory quotients of both iron-rich and iron-poor cocci (Table 2), when considered in conjunction with the oxidation state of the accumulated end-products, are in reasonable agreement with the calculated theoretical values based on complete oxidation of the substrate to $\mathrm{CO}_{2}$ and water.

\section{End-product analysis studies on iron-rich and iron-poor Staphylococcus aureus grown in the presence of glucose}

Figure 3 records the $\mathrm{O}_{2}$ uptake by $\mathrm{Fe}+\mathrm{G}+$ and $\mathrm{Fe}-\mathrm{G}+$ cocci on selected substrates. In contrast to $\mathbf{F e}+\mathbf{G}-$ cocci (Figs. 1, 2), $\mathbf{F e}+\mathbf{G}+$ cocci were unable to use acetate, malate, succinate or citrate. Glucose, L-lactate, D-lactate and pyruvate were oxidized at decreased rates and incompletely, while formate was oxidized to the same extent by $\mathbf{F e}+\mathbf{G}-$ cocci, but at a slower rate. With $\mathbf{F e}-\mathbf{G}+$ cocci only glucose was oxidized. The total $\mathrm{O}_{2}$ consumed by these cocci was onequarter that of the $\mathrm{Fe}-\mathrm{G}-$ cocci. 
Table 3 summarizes the end-product analyses of the substrates oxidized by $\mathrm{Fe}+\mathbf{G}+$ and $\mathbf{F e}-\mathbf{G}+$ cocci. The products of glucose oxidation by the $\mathrm{Fe}+\mathrm{G}+$ cocci in percentages of initial carbon available were: $\mathrm{CO}_{2}, 38 \%$; acetate, $24 \%$; lactate, $8 \%$. L-Lactate was oxidized to $\mathrm{CO}_{2}, 49 \%$, acetate, $18 \%$; and pyruvate, $11 \%$. Only $10 \%$ of the D-lactate was used, with $40 \%$ of this amount being converted to acetate and $40 \%$ to $\mathrm{CO}_{2}$. It is possible that D-lactate was not used at all but was contaminated with some L-lactate that was readily used. At the time of analysis, $46 \%$ of the initially available pyruvate had been metabolized and was accounted for as $\mathrm{CO}_{2}, 40 \%$; acetate, $51 \%$; and lactate, $10 \%$. All the formate was utilized, with $88 \%$ accounted for as $\mathrm{CO}_{2}$. The end products of glucose oxidation by $\mathrm{Fe}-\mathrm{G}+$ cocci were: $\mathrm{CO}_{2}, 12 \%$; acetate, $12 \%$; lactate, $64 \%$; pyruvate, $10 \%$; acetoin, $11 \%$; at the time of analysis, no glucose remained.

Table 3. Substrate dissimilation by suspensions of iron-rich and iron-poor Staphylococcus aureus grown in the presence of glucose*

Experimental details as for Fig. 3

\begin{tabular}{|c|c|c|c|c|c|c|c|c|c|}
\hline \multirow[b]{2}{*}{ Substrate } & \multicolumn{8}{|c|}{ Experimental details as for Fig. 3} & \multirow{2}{*}{$\begin{array}{c}\% \\
\text { carbon } \\
\text { recovered }\end{array}$} \\
\hline & Organisms & Lactate & Pyruvate & Acetate & Acetoin & $\mathrm{CO}_{2}$ & $\mathbf{O}_{2}$ & R.Q. & \\
\hline Glucose & $\begin{array}{l}\mathbf{F e}+\mathbf{G}+ \\
\mathbf{F e}-\mathbf{G}+\end{array}$ & $\begin{array}{l}0.15 \\
1.28\end{array}$ & $\begin{array}{l}0 \\
0 \cdot 19\end{array}$ & $\begin{array}{l}0 \cdot 704 \\
0 \cdot 35\end{array}$ & $\begin{array}{l}0 \\
0 \cdot 17\end{array}$ & $\begin{array}{l}2 \cdot 3 \\
0.70\end{array}$ & $\begin{array}{l}2 \cdot 34 \\
0 \cdot 61\end{array}$ & $\begin{array}{l}0 \cdot 98 \\
1 \cdot 15\end{array}$ & $\begin{array}{r}70 \\
108\end{array}$ \\
\hline L-Lactate & $\begin{array}{l}\mathbf{F e}+\mathbf{G}+ \\
\mathbf{F e}-\mathbf{G}+\end{array}$ & $\begin{array}{l}0 \\
1.01\end{array}$ & $\begin{array}{l}0 \cdot 112 \\
0\end{array}$ & $\begin{array}{l}0 \cdot 274 \\
0\end{array}$ & $\begin{array}{l}\mathbf{0} \\
\mathbf{0}\end{array}$ & $\begin{array}{l}1 \cdot 49 \\
0\end{array}$ & $\begin{array}{l}1 \cdot 52 \\
0\end{array}$ & $\begin{array}{l}0 \cdot 97 \\
-\end{array}$ & $\begin{array}{r}79 \\
101\end{array}$ \\
\hline D-Lactate & $\begin{array}{l}\mathbf{F e}+\mathbf{G}+ \\
\mathbf{F e}-\mathbf{G}+\end{array}$ & $\begin{array}{l}0.9 \\
1.06\end{array}$ & $\begin{array}{l}\mathbf{0} \\
\mathbf{0}\end{array}$ & $\begin{array}{l}0 \cdot 058 \\
0\end{array}$ & $\begin{array}{l}\mathbf{0} \\
\mathbf{0}\end{array}$ & $\begin{array}{l}\mathbf{0} \cdot 116 \\
0\end{array}$ & $\begin{array}{l}0 \cdot 104 \\
0\end{array}$ & $1 \cdot 11$ & $\begin{array}{r}98 \\
106\end{array}$ \\
\hline Pyruvate & $\begin{array}{l}\mathbf{F e}+\mathbf{G}+ \\
\mathbf{F e}-\mathbf{G}+\end{array}$ & $\begin{array}{l}0.05 \\
0\end{array}$ & $\begin{array}{l}0.537 \\
1.00\end{array}$ & $\begin{array}{l}0.851 \\
0\end{array}$ & $\begin{array}{l}\mathbf{0} \\
\mathbf{0}\end{array}$ & $\begin{array}{l}0 \cdot 56 \\
0\end{array}$ & $\begin{array}{l}0 \cdot 46 \\
0\end{array}$ & $1 \cdot 37$ & $\begin{array}{l}101 \\
100\end{array}$ \\
\hline Formate & $\begin{array}{l}\mathbf{F e}+\mathbf{G}+ \\
\mathbf{F e}-\mathbf{G}+\end{array}$ & $\begin{array}{l}\mathbf{0} \\
\mathbf{0}\end{array}$ & $\begin{array}{l}\mathbf{0} \\
\mathbf{0}\end{array}$ & $\begin{array}{l}\mathbf{0} \\
\mathbf{0}\end{array}$ & $\begin{array}{l}\mathbf{0} \\
\mathbf{0}\end{array}$ & $\begin{array}{l}\mathbf{0 \cdot 8 8} \\
0\end{array}$ & $\begin{array}{l}\mathbf{0} \cdot 58 \\
0\end{array}$ & 1.52 & $\mathbf{8 8}$ \\
\hline
\end{tabular}

* Results expressed as $\mu$ mole $/ \mu$ mole substrate consumed. $\mathrm{O}_{2}$ and $\mathrm{CO}_{2}$ corrected for endogenous. $\uparrow$ No glucose detected in supernatant fluids.

\section{Glycolytic activity of iron-rich and iron-poor staphylococci}

To determine the glycolytic activity of iron-rich and iron-poor Staphylococcus aureus when grown aerobically in the absence or presence of glucose, glucose fermentation studies were made (Fig. 4; Table 4). Fe+ G- cocci fermented glucose anaerobically at approximately one-third to one-quarter the rate of the $\mathrm{Fe}-\mathrm{G}-$ cocci. When grown in the presence of glucose, iron-rich and iron-poor cocci both fermented this substrate at about the same rate and to the same extent. In all cases (Table 4), the products of glycolysis were mostly lactate (73-94\%), acetate (4-7\%) and traces of pyruvate. These results show that growth on glucose enhanced the glycolytic activity of iron-rich cocci while the activity of iron-poor cocci was high and essentially the same, irrespective of the presence or absence of glucose in the growth medium. It appears that the iron-poor cocci deficient in normal respiratory activity relied on anaerobic fermentation and thus showed high activities of glycolyzing enzymes even in the absence of glucose. The acetate found probably resulted from the dismutation of pyruvate. Studies on the pyruvate dismutation activity of these organisms grown in absence of glucose showed that iron-rich cocci were 


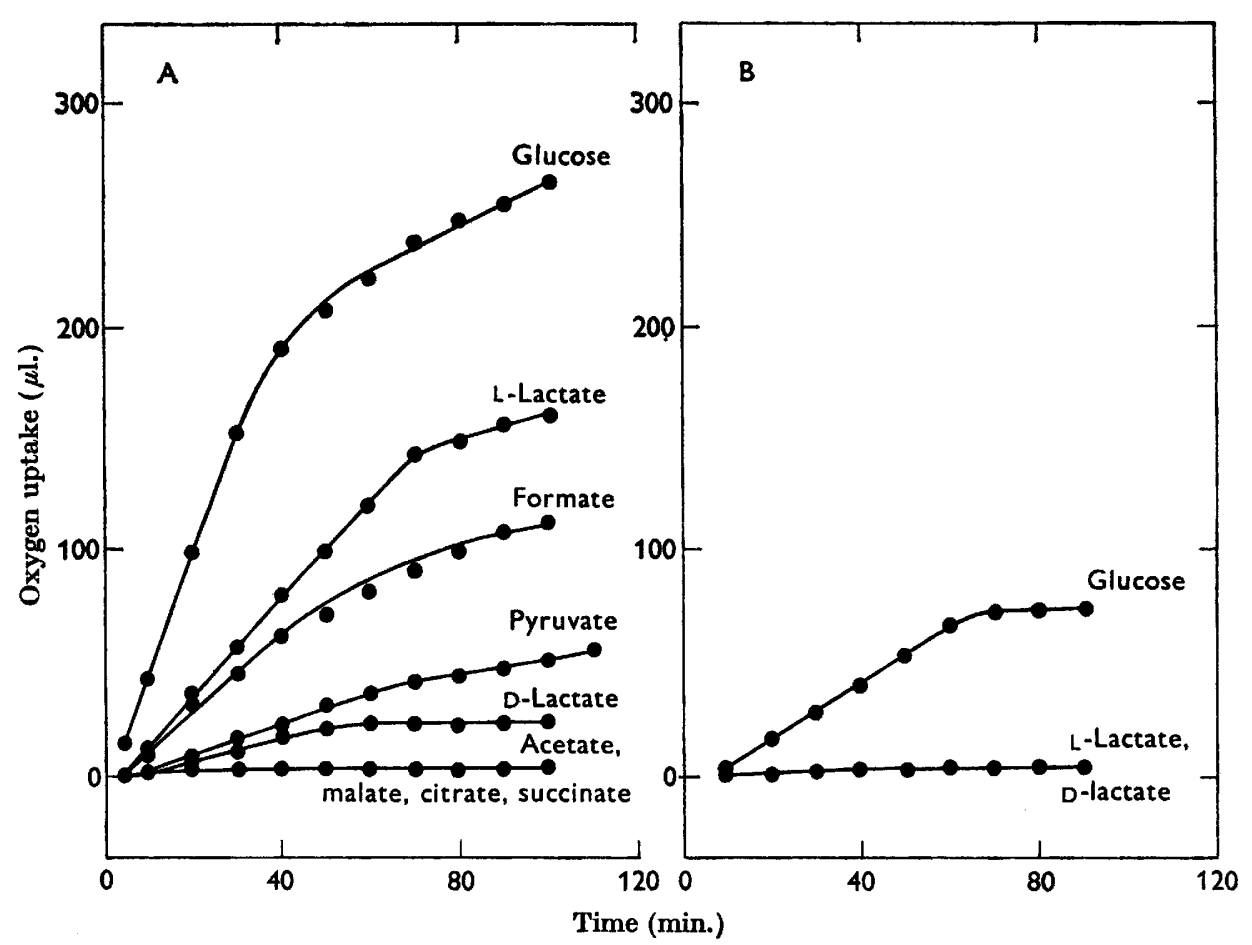

Fig. 3. Oxidation of various substrates by iron-rich and iron-poor Staphylococcus aureus grown in the presence of glucose. A, Fe $+\mathbf{G}+\operatorname{cocci} ; \mathrm{B}, \mathrm{Fe}-\mathrm{G}+$ cocci. Experimental details as in Table 1 ; substrates used expressed as $\mu$ moles: glucose, 5 ; L-lactate, 5; D-lactate, 5; pyruvate, 5; succinate, 5; malate, 5; citrate, 5; acetate, 10; formate, 10. Endogenous values subtracted.

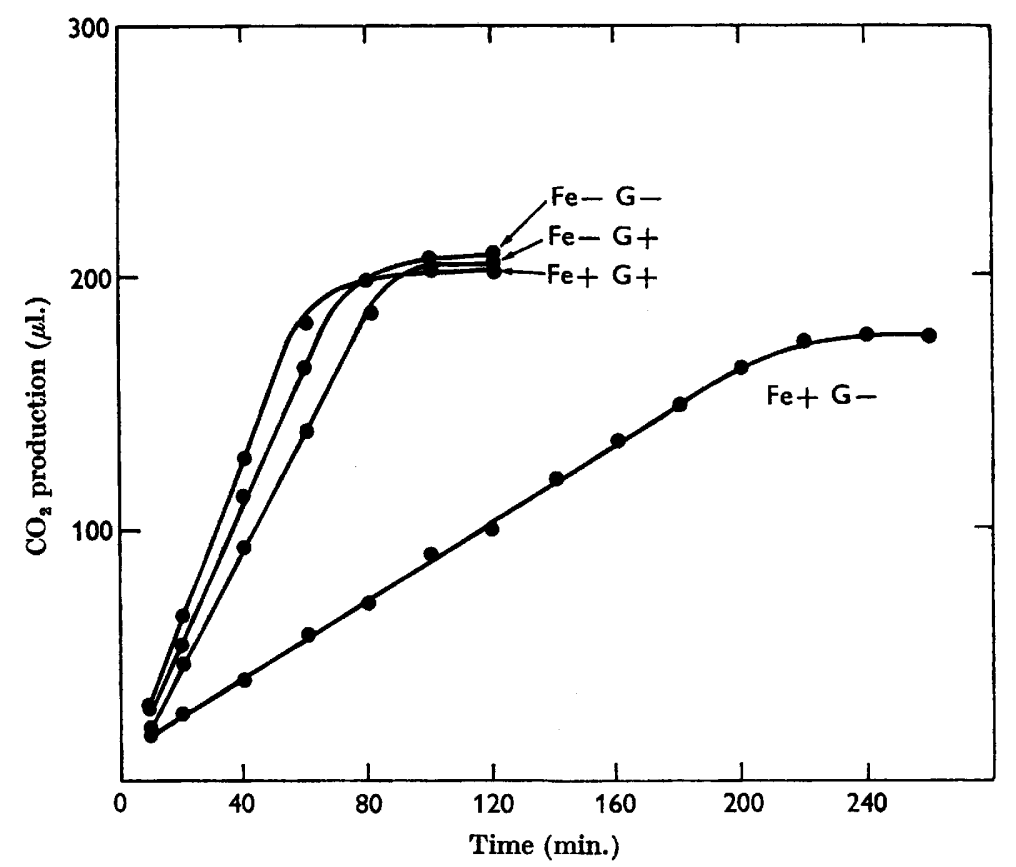

Fig. 4. Glycolytic activity by suspensions of iron-poor and iron-rich Staphylococcus aureus grown in the absence or presence of glucose. The experimental details are as described in Table 4. 
three times as active as the iron-poor cocci ( $Q$ of high-Fe $=99$ versus $Q$ of low$\mathrm{Fe}=31$, where $Q=\mu \mathrm{l} . \mathrm{CO}_{2} / \mathrm{hr} / \mathrm{mg}$. dry wt. organism).

\section{Catalase activity of iron-rich and iron-poor cocci}

When iron-rich and iron-poor staphylococci grown in the absence of glucose were compared for their relative catalase activities, Fe - G - cocci $(Q=1 \cdot 3)$ were practically devoid of this iron-containing enzyme while $F e+G-\operatorname{cocci}(Q=43)$ as expected were relatively rich. Of particular interest was the apparent inhibitory effect that glucose had on the catalase activity of organisms grown in the medium containing high-Fe + glucose. $\mathrm{Fe}+\mathrm{G}+\operatorname{cocci}(Q=8 \cdot 6)$ possessed only $20 \%$ of the activity of cocci grown in the absence of glucose. $F e-G+\operatorname{cocci}(Q=2 \cdot 5)$, like the $\mathbf{F e}-\mathbf{G}-$ cocci, were practically devoid of any catalase activity ( $Q$ values $=\mu$ moles $\mathrm{O}_{2}$ produced/min./mg. dry wt. cocci).

Table 4. Rate of glycolysis and products of glucose dissimilation by suspensions of iron-poor and iron-rich Staphylococcus aureus grown aerobically in the absence or presence of glucose*

Warburg vessels contained equiv. 3.2 mg. dry wt. cocei in $2.0 \mathrm{ml}$. 0.03 $\mathrm{m}-\mathrm{NaHCO}_{8}$, $(\mathrm{pH} 7 \cdot 4) ; 5 \mu$ mole of glucose were added from the sidearm; total volume $2 \cdot 1 \mathrm{ml}$. The gas phase was $90 \%(\mathrm{v} / \mathrm{v}) \mathrm{N}_{2}+10 \%(\mathrm{v} / \mathrm{v}) \mathrm{CO}_{2}$. Temp. $37^{\circ} . Q_{\mathrm{O}_{2}}$ values represent $\mu \mathrm{l} . \mathrm{CO}_{2}$ produced/hr/mg. dry wt. cocci.

\begin{tabular}{|c|c|c|c|c|c|c|}
\hline Organisms & $\begin{array}{c}\mathbf{Q}_{\mathrm{O}_{\mathbf{2}}} \\
\text { values }\end{array}$ & Lactate & Pyruvate & Acetate & Acetoin & $\begin{array}{l}\% \text { carbon } \\
\text { recovered }\end{array}$ \\
\hline $\mathbf{F e}-\mathbf{G}-$ & 58 & 1.78 & 0.02 & $0 \cdot 13$ & $\mathbf{0}$ & 94 \\
\hline $\mathbf{F e}+\mathbf{G}-$ & 16 & $1 \cdot 45$ & 0.02 & $0 \cdot 21$ & $\mathbf{0}$ & 81 \\
\hline $\mathbf{F e}-\mathbf{G}+$ & 44 & $1 \cdot 88$ & 0.01 & $0 \cdot 15$ & 0 & 102 \\
\hline $\mathbf{F e}+\mathbf{G}+$ & 63 & $1 \cdot 65$ & 0.02 & $0 \cdot 18$ & $\mathbf{0}$ & 90 \\
\hline
\end{tabular}

\section{DISCUSSION}

Theodore \& Schade (1965) showed that the growth rate of a strain of Staphylococcus aureus $80 / 81$ in iron-restricted trypticase media was dependent on the amount of free ionic iron available to the organism. Addition of glucose to such media at all concentrations of iron investigated increased further the logarithmic growth rate. The responses of these bacteria to iron and glucose additions made investigation of their metabolic characteristics of especial interest since their growth-rate patterns followed those of the same strain grown in human serum at various concentrations of siderophilin-iron saturation (Schade, 1963). Comparison of the metabolic activities of iron-rich and iron-poor staphylococci grown in the absence of glucose showed the high oxidative capacity of $\mathrm{Fe}+\mathrm{G}-$ cocci and the decreased and impaired oxidative capacity of the $\mathrm{Fe}-\mathrm{G}-$ cocci. In some respects, these results are similar to findings of Waring \& Werkman (1944) and Webley, Duff \& Anderson (1962) who studied the metabolic activities of iron-deficient glucose-grown Aerobacter aerogenes and Nocardia opaca, respectively.

Suspensions of $\mathrm{Fe}+\mathrm{G}-$ Staphylococcus aureus oxidized glucose, L-lactate, Dlactate, pyruvate, acetate and formate completely to $\mathrm{CO}_{2}$ and water at rapid rates. Krebs cycle intermediates (malate, succinate) were also rapidly oxidized, apparently to completion. Citrate was oxidized at a decreased rate in comparison to other 
Krebs cycle intermediates, probably because of the impermeability of the cocci to this substrate (Stedman \& Kravitz, 1955). Fe- G- staphylococci, however, oxidized only glucose, L-lactate and D-lactate, at decreased rates, and incompletely, in contrast to $\mathrm{Fe}+\mathrm{G}-$ staphylococci. Pyruvate, acetate, formate and Krebs cycle intermediates were not used. The inability of these organisms to use pyruvate suggests that the pyruvic oxidase of this $S$. aureus may be iron dependent. O'Kane (1954) showed that the pyruvic oxidase of Clostridium butyricum required ferrous iron. The end-products from glucose and L-lactate metabolism by $\mathrm{Fe}-\mathrm{G}$ - staphylococci were $\mathrm{CO}_{2}$, acetate and acetoin, while only $\mathrm{CO}_{2}$ and acetate resulted from D-lactate utilization. That pyruvate was not found as an end-product of these oxidations and was itself not used as a substrate suggested that either glucose and lactate are converted to acetate and $\mathrm{CO}_{2}$ by a lactate oxidase system similar to that found in mycobacteria (Sutton, 1954) and not involving pyruvate; or that $\mathrm{Fe}-\mathrm{G}-$ cocci are impermeable to exogenous pyruvate. To account, however, for the production of acetoin from glucose and L-lactate without pyruvate as an intermediary is not possible on the available evidence. Further, since the $\mathrm{CO}_{2}$ produced from the oxidation of glucose and lactate was in considerable excess of that expected from the quantity of acetate found as end product, assuming that the path of such oxidations is via lactate to acetate and $\mathrm{CO}_{2}$, and since acetate is demonstrably not oxidized, some other metabolic oxidative system must be operative in these organisms. The percentages of carbon recovered indicate some assimilation of these substances. The possibility exists that the excess $\mathrm{CO}_{2}$ was derived from oxidation of an assimilated material.

The results obtained with iron-rich staphylococci when grown with and without glucose were similar to those found by Collins \& Lascelles (1962), Gershanovitch, Palkina \& Burd (1963), and Strasters \& Winkler (1963) who showed that growth on glucose repressed the formation of enzymes required for the oxidation of acetate and tricarboxylic acid cycle intermediates. In the present work, $\mathrm{Fe}+\mathrm{G}+$ staphylococci not only did not oxidize these substrates, but also produced acetate as an end product from glucose, L-lactate and pyruvate. Fe - G - staphylococci, with their already impaired respiratory activity, were so inhibited by the presence of glucose that they did not oxidize L- or D-lactate and only slowly attacked glucose itself. The accumulation of large amounts of lactate from glucose oxidation suggested that there was increased reliance on anaerobic fermentation for energy production necessary to growth and maintenance of the $\mathbf{F e}-\mathbf{G}+$ staphylococci. From these results, it can be seen that the metabolic activity of Staphylococcus aureus was affected not only by the amount of available iron in the medium but also by the presence or absence of glucose. Since there are many examples in the literature of repression of enzyme synthesis by glucose, any studies of the metabolic capacities of organisms as affected by a particular nutrient, e.g. iron, must consider the possibility of misinterpretation of data when glucose has been used as the common carbon + energy source. For instance, $\mathbf{F e}-\mathbf{G}+$ staphylococci did not use L- or D-lactate and only slowly oxidized glucose with the accumulation of large amounts of lactate. These findings, considered by themselves, might have been ascribed to iron deficiency, however, they were actually due to glucose inhibition since $\mathrm{Fe}-\mathrm{G}$ - staphylococci grown in the absence of glucose were able to oxidize L- and D-lactate and to oxidize glucose without accumulation of lactate. 


\section{REFERENCES}

Barker, H. A. \& Summerson, J. H. (1941). The colorimetric determination of lactic acid in biological material. J. biol. Chem. 138, 535.

Coluins, F. M. \& Lasceluse, J. (1962). The effect of growth conditions on oxidative and dehydrogenase activity in Staphylococcus aureus. J. gen. Microbiol. 29, 531.

Friedemann, F. M. \& Haugen, G. E. (1943). Pyruvic acid. II. The determination of keto acids in blood and urine. J. biol. Chem. 147, 415 .

Gerhenanovitch, V. N., Palkina, N. A. \& Burd, G. I. (1963). The role of lactate in regulation of the enzymatic system synthesis participating in the acetate oxidation of Staphylococcus aureus. Biochem. biophys. Res. Commun. 13, 12.

O'Kane, B. G. (1954). Non-lipoic systems: acetate formation by Proteus and acetyl phosphate formation by Clostridium. Fed. Proc. 13, 739.

Schade, A. L. (1960). Protides of Biological Fluids, p. 261. Proc. 8th Colloq. Bruges. Amsterdam: Elsevier Publishing Co.

Schade, A. L. (1963). Significance of serum iron for the growth, biological characteristics, and metabolism of Staphylococcus aureus. Biochem. Z. 338, 140.

Schade, A. L. \& Caroline, L. (1944). Raw hen egg white and the role of iron in growth inhibition of Shigella dysenteriae, Staphylococcus aureus, Escherichia coli, and Saccharomyces cerevisiae. Science, 100, 14

Schade, A. L., Oyama, J., Reinhart, R. W. \& Miluer, J. R. (1954). Bound iron and unsaturated iron-binding capacity of serum; rapid and reliable quantitative determination. Proc. Soc. Exp. Biol. Med. 87, 443.

Soodak, M. (1957). An enzymatic micromethod for the determination of acetate. Meth. Enzymol. 3, 266.

Stedman, R.L. \& Kravitz, E. (1955). Evidence for a common pathway for pyruvate and acetate oxidation by Micrococcus pyogenes var. aureus. Archs. Biochem. Biophys. 59, 260.

Strasters, K. C. \& Winkuer, K. C. (1963). Carbohydrate metabolism in Staphylococcus aureus. J. gen. Microbiol. 33, 213.

Sutron, W. B. (1954). Isolation and properties of a lactic oxidative decarboxylase from Mycobacterium phlei. J. biol. Chem. 210, 309.

Theodore, T. S. \& Schade, A. L. (1965). Growth of Staphylococcus aureus in media of restricted and unrestricted inorganic iron availability. J. gen. Microbiol. 39, 75.

Umbreit, W. W., Burris, R. H. \& Stauffer, J. F. (1957). Manometric Techniques, 3rd ed. Minneapolis: Burgess Publishing Co.

Waring, W. S. \& Werkman, C. H. (1944). Iron deficiency in bacterial metabolism. Arch. Biochem. 4, 75 .

Webley, D. M., Duff, R. B. \& Anderson, G. (1962). The metabolism of iron-, zinc-, and manganese-deficient Nocardia opaca. J. gen. Microbiol. 29, 179.

Westerfeid, W. W. (1945). A colorimetric determination of blood acetoin. J. biol. Chem. 161, 495. 